\title{
The De-standardisation of Early Family Trajectories in the Czech Republic: A Cross-cohort Comparison*
}

\author{
JANA CHALOUPKOVÁ** \\ Institute of Sociology, Academy of Sciences of the Czech Republic, Prague
}

\begin{abstract}
Drawing upon the trajectory-based (holistic) approach, this article compares early family trajectories observed during the socialist period with those after the transition to a market economy in the Czech Republic. It aims (1) to provide an empirical analysis of change in the heterogeneity of early family trajectories between the ages of 18 and 35 and (2) to identify their distinct patterns. To do this an entropy index and optimal matching analysis is applied. The paper uses data from the ISSP 2002, which included questions on partnership and family history in the Czech Republic. The findings show that the process of de-standardisation is quite complex and non-uniform. Cohorts born from the 1970s on experience more diverse early family trajectories than older cohorts, mainly due to increasing unmarried cohabitation. However, in the cohort born in the 1980s we can observe a reversal trend of declining diversity of family statuses in the subjects' early twenties due to the postponement of family related transitions. Even among older birth cohorts, who experienced their family starts under the socialist regime, it is possible to find a certain plurality of family starts, differentiated by the level of education.
\end{abstract}

Keywords: life course de-standardisation, family trajectory, sequence analysis, ISSP 2002, Czech Republic

Sociologický časopis/Czech Sociological Review, 2010, Vol. 46, No. 3: 427-451

The development of modern age-stratified institutions, such as the education and pension systems, had an important impact on the emergence of the standardised life course [Kohli 1986]. Since the late 1960s there has been a discussion about whether this trend has been replaced by processes of de-standardisation and deinstitutionalisation. These changes are the result of increasing individualisation and a weakening of the social norms that organise the life course. Many social theorists argue that values and personal preferences are gaining more importance in individual biographies and that individual life courses are becoming

\footnotetext{
* This research was made possible by support from the Grant Agency of the Academy of Sciences of the Czech Republic, project no. KJB700280802.

** Direct all correspondence to: Jana Chaloupková, Institute of Sociology, Academy of Sciences of the Czech Republic, Jilská 1, 11000 Prague 1, Czech Republic, e-mail: jana.chaloupkova@soc.cas.cz.
}

(C) Sociologický ústav AV ČR, v.v.i., Praha 2010 
more diverse, more flexible, and more unpredictable [Beck 2004]. Others argue that the growing diversity and instability of individual life trajectories is linked to greater instability in the labour market owing to increased global competition [Mills and Blossfeld 2005].

In recent decades, the life course has come to assume increasing importance in the social sciences [Giele and Elder 1998; Levy and Krüger 2001] and more and more attention has been paid to critically examining the hypothesis about the destandardisation of the life course. This critical examination relates to efforts to conceptualise the various dimensions of these processes [Brückner and Mayer 2005] and to develop statistical measures of change in the heterogeneity of life trajectories [Elzinga and Liefbroer 2007; Fussell 2005; Fussell, Gauthier and Evans 2007].

Although terms like 'de-standardisation', 'de-institutionalisation', 'differentiation', and 'pluralisation' are often used interchangeably, on closer examination they pertain to different dimensions and may occur independently or even incoherently. It is necessary to define and distinguish between these different dimensions in order to study them systematically and to formulate empirically testable hypotheses [Brückner and Mayer 2005; Elzinga and Liefbroer 2007]. Deinstitutionalisation refers to the progressive weakening of the social norms that regulate the organisation of time in the life course and reflects the fact that different stages or states in the life course are becoming more blurred. De-standardisation means that life courses are becoming less uniform and reflects the fact that certain life events are experienced by smaller and smaller shares of the population, occurring at more diverse ages and for durations that vary more widely. Differentiation denotes the increase in the number of distinct states or stages within individual life courses (e.g. unmarried cohabitation before marriage), whereas pluralisation refers to the increase in the number of synchronous states in a population (e.g. family forms) [Brückner and Mayer 2005]. As mentioned above, these processes can take different directions. For instance, the pluralisation of family forms may be accompanied by standardisation processes (e.g. when unmarried cohabitation becomes an almost universal precursor of marriage) and may result in the emergence of a 'new standard life course' [Brückner and Mayer 2005].

The study of de-standardisation processes has revealed that, rather than being a general and uniform trend, de-standardisation proceeds at a distinct pace in several respects. First, the pace of de-standardisation of the life course differs across life domains. Although there is evidence for a growing variety of family trajectories in Western European countries over recent decades, the findings for work trajectories are less clear [Brückner and Mayer 2005]. Second, the pace of de-standardisation varies importantly at the country level. Comparing data for cohorts born in 1945-1964, Elzinga and Liefbroer [2007] observed increased variation of family trajectories in most Western European countries. Conversely, in the former communist countries of Central and Eastern Europe the cohort differences were quite small. Contrary to the authors' expectations, data for Sweden and to some extent also for the Netherlands showed decreasing variation of early 
family trajectories between individuals, which might suggest a 'new standard life course' is emerging in these countries. Conversely, empirical evidence does not confirm that family trajectories have become more turbulent, even in countries like Sweden or the Netherlands, which are often considered the frontrunners of demographic change [Elzinga and Liefbroer 2007]. Finally, there is also evidence that the extent of de-standardisation varies across social groups and impacts men and women in different degrees [Widmer and Ritschard 2009].

To date most studies on changes in life course patterns have focused on Western countries, while studies of post-communist countries have been scarce [Baranowska 2008]. However, studying the post-communist countries of Central and Eastern Europe that experienced a transformation in institutional and economic conditions in the 1990s and saw family behaviour change rapidly might provide new insight into the process of life course de-standardisation. In this article, early family trajectories observed during the socialist period will be compared with those observed after the transition to a market economy in the Czech Republic.

The article is structured as follows. The first section provides a brief overview of the development of family behaviour in the Czech Republic and elaborates the hypothesis about changes in family trajectories. The next section provides a description of the data and methodology, and then the results of the empirical analyses are presented. The article concludes with a discussion of the empirical findings and the limitations of available data.

\section{The development of family behaviour in the Czech Republic}

Although Western European countries have experienced changes in demographic behaviour since the 1960s, in the Czech Republic no major changes began until the fall of communism in 1989. During the 1990s the Czech Republic underwent profound economic, social, and political changes: the transformation from a centrally planned to a market economy and the establishment of democratic political structures. These changes had an important effect on the range of opportunities in the labour market and the education system, but also presented young people with an increased risk of job instability and unemployment. The value of education has risen since 1989 and education has become a more important factor for people's employment prospects and level of income [Večerník 1999].

Like other East European countries, the Czech Republic experienced a significant decline in period fertility and nuptiality rates after the fall of communism. Demographic changes included the postponement of childbearing, an increase of childbearing outside marriage, and the growing popularity of unmarried cohabitation [Sobotka et al. 2008]. The median age of women at first childbirth increased by more than five years between 1990 and 2005 (from 22.5 to 26.6 years of age) [Sobotka et al. 2008]. Family behaviour under socialism was characterised 
by early and almost universal marriage and early family formation. During the socialist period it was normal for women to have children at a young age, and consequently motherhood often preceded entry to the labour market [Alan 1989]. Previous studies using biographical data have shown that since 1989 the ages at which young people commence building their professional and family lives have grown further apart and the period spent in the labour market before the birth of a first child has lengthened [Paloncyová 2002]. These changes affected the birth cohorts born in the 1970s and later, while young people born up to the mid-1960s had fertility histories similar to those observed in the 'state socialist' era. The shift in timing of the first childbirth resulted in a bimodal distribution of first-birth intensities by age for the cohort of women born in 1970-1974 [Sobotka et al. 2008]. In other words, while in the younger cohort (born in the mid-1970s and later) the highest first-birth intensities shifted to a later age, the 1970-1974 cohort divided into two groups: one group followed the old 'socialist model' of family formation in their early twenties and the other delayed childbirth to their late twenties. The postponement of childbearing is coupled with rising educational differences in first childbirth timing. The prolonging of the period of childlessness is pronounced among highly educated women [Kantorová 2004; Sobotka et al. 2008]. Moreover, the context of family formation is increasingly differentiated by education level. Women with low education levels are much more likely to have their first child outside marriage [Hamplová et. al. 2007].

\section{Research questions and hypotheses}

In this article I am using retrospective survey data to describe cross-cohort variation in early family trajectories. The article will focus on one specific aspect of family trajectory de-standardisation and pluralisation and will explore whether the variety of family trajectories increases across cohorts.

The analyses are divided into two parts. In the first part, we will focus on the question whether early family trajectories have become more diverse over time. More specifically, we are interested in changes affecting the heterogeneity of family situations among persons of the same age across birth cohorts. The available data (see below for more details) provide information on the family situations of persons born 1919-1984. In the second part, I will focus only on persons aged 35 years or older (born 1919-1967) and we will try to identify distinct patterns of early family trajectories. Although family formation was strongly standardised under the communist regime [Elzinga and Liefbroer 2007], and although the common picture of demographic changes juxtaposes an allegedly uniform socialist pattern of marriage and first childbirth at relatively low ages to the postcommunist diversity of family trajectories, including new family forms and more diverse timing of family formation, one might ask if this is the whole picture. Can we identify, beneath the seeming uniformity of the socialist regime, any distinct patterns of family trajectories that differ in the timing or sequencing of events? 
The degree of heterogeneity of status combinations is expected to be smaller under the communist regime, when social institutions and social norms strongly influenced the timing of family events. On the other hand, one would expect greater heterogeneity of age-specific family situations after 1989, as the norms guiding the life course became more relaxed and a range of new opportunities emerged. The age-specific status combinations reflect changes both in the timing of life-course transitions and the degree of pluralisation and differentiation of family forms.

Conversely, the postponement of family formation and the longer period spent studying, which might even delay entry to cohabitational unions, mean that we may paradoxically be witnessing a 'simplification' of family situations among the youngest cohorts in their early twenties, because an increasing proportion of individuals do not enter parenthood and some also do not enter partnership unions [Widmer and Ritschard 2009]. Similarly, Hamplová found that cohorts born in the 1970s in the Czech Republic have an overall lower probability of union formation, regardless of their formal status. She thus found that the decline in the Czech Republic's marriage rate over the 1990s was not fully compensated by the spread of unmarried cohabitation [Hamplová 2003a]. The heterogeneity of family situations can be expected to increase over time at a different pace for men and women, as women's early family trajectories are more diverse than men's because men postpone family-related transitions to a higher age.

\section{The effect of education}

We might assume that women with different human capital have different family career patterns. The economic approach assumes that for women with higher human capital investment, marriage is less attractive and childbearing is postponed [Becker 1993]. On the other hand, it has been argued that it is not education level that plays the main role in the postponement of family formation, ${ }^{1}$ but rather that educational enrolment is more important. Being a student is seen as incompatible with union and family formation because the normative expectations about lifecourse sequencing suggest that it is necessary to finish one's studies and get a job before having family [Blossfeld and Huinink 1991]. This relationship may depend on the institutional context, as public policy can provide childcare opportunities and financial support to students that make childbearing more compatible with student status. Moreover, timing childbearing before entering the labour market can be seen as strategy to minimise career interruptions in the subsequent employment trajectory, as was especially the case in the conditions created by the

\footnotetext{
${ }^{1}$ However, the reverse relationship also exists between educational attainment and family formation, because early transition to union and to parenthood can trigger an earlier dropout from the education system.
} 
centrally planned economies in the former communist countries, where careers were highly predetermined [Kreyenfeld 2000, 2004]. Comparing East and West Germany before unification, Kreyenfeld found that in East Germany educational enrolment and parenthood were more compatible and that being in education reduced the first-birth risks to a level much lower than in West Germany [Kreyenfeld 2000]. Differences in the age of women at first birth in East Germany (1952-1972 cohort) can be explained by the length of educational participation [Kreyenfeld 2004]. Under the socialist regime, thanks to available childcare and the limited mobility chances, the first-birth risk was higher among highly educated women and they become mothers quickly after they finished their degree [Kreyenfeld 2000, 2004]. Findings for the Czech Republic based on data from the Family and Fertility Survey (FFS) in 1997 confirmed that that longer enrolment in full-time study is associated with the postponement of the transition to partnership [Hamplová 2003b]. Similarly, Billari and Philipov [2004] concluded that first union formation is linked more to the end of education than to the level of education attained. However, since the transition to a market economy, when opportunities for upward mobility increased, educational attainment has had a greater impact on the postponement of a first union in Central and Eastern European countries [Billari and Philipov 2004].

Even under the communist regime, when career opportunities were limited and there was full employment, we might expect some variability of early family careers according to the level of education. Since the fall of communism, the costs of 'lost opportunities' due to childbearing may have become higher and it may have become more difficult to reconcile family and a career. Czech society has long been characterised by a high rate of female employment, typically working full time, with relatively long breaks for childcare. Maternity/parental leave was progressively extended from the 1960s and in 1990 it was finally extended to a period of three years after the birth of a child. At the same time, during the 1990s the availability of public childcare facilities declined in the Czech Republic compared to what was available in the socialist period [Kocourková 2002]. Therefore, the variation in the timing of family formation by education level is expected to increase. Also, it can be expected that since the transition to a market economy enrolment in full-time study and parenthood have become more incompatible [Kreyenfeld 2000].

With the transition to a market economy and exposure to global competition, young adults began to face rising uncertainty, which might discourage them from making long-term commitments and hence contribute to the postponement of family formation. Men's economic uncertainty has the most profound impact on family formation in social contexts where the male-breadwinner model is strong [Mills and Blossfeld 2005]. For example, analysis on Swiss data confirmed that less-educated men who follow non-continuous, unstable work trajectories have a greater likelihood of postponing entering into stable partnerships and childbearing [Levy, Gauthier and Widmer 2006]. Conversely, female unemploy- 
ment or poor job prospects might reduce the opportunity costs and thus foster family formation. Given the fact that the two-income family has become the norm in Czech society, job instability can be expected to have a negative impact on both men's and women's family formation.

To conclude, the analysis presented here does not address the effects of education level, educational enrolment, and economic uncertainty on the timing of family formation directly, but we focus here only on the question of whether the variation in early family patterns is connected with the level of completed education.

\section{Data and methodology}

From the methodological point of view, two main approaches to the study of the life course can be distinguished: an event-based approach and a holistic (trajectory-based) approach [Billari 2001, 2005]. Event-history analysis enables us to understand the variation in the timing of individual transitions and to reveal the odds of experiencing certain events (e.g. childbirth, marriage). This approach aims to show which group is more likely to experience certain transitions earlier or later than others, but it most often focuses on just a single event. However, the life-course perspective rests on the assumption that transitions are closely interrelated and focuses not only on the timing of events, but also on the order in which they occur. Moreover, the focus on single events overlooks the fact that these transitions can be unstable or reversible and that many transitions are part of a complex process. On the other hand, the holistic or trajectory-based approach focuses on individual trajectories (sequences of states), rather than specific events or individual transitions. Thus, it takes into account the timing, sequencing, and quantum of life-course events simultaneously [Billari 2001]. Methodologically, this approach is based on sequence analysis [Abbott and Hrycak 1990; BrzinskyFay, Kohler and Luniak 2006; Macindoe and Abbott 2006]. The trajectory-based approach enables us to address the heterogeneity of individual pathways and to identify patterns of similar trajectories. The aim of this article is to employ the holistic or trajectory-based approach to find whether there was any variability in early family trajectories under socialism and whether individual life courses have become more diverse over time.

The analysis is based on retrospective data on family history collected in a supplement to the Czech 2002 International Social Survey Programme (ISSP) on 'Family and Changing Gender Roles'. The national probability sample contains 1289 respondents aged 18 years or older and an oversample of 373 persons up to 35 years of age. Although the analysis of family trajectories between the ages of 18 and 35 years deals with completed trajectories and thus only includes persons aged 35 years or older (i.e. 530 women and 299 men born 1919-1967), the analysis of age-specific status combinations focuses on all persons, including the over- 
sample of young people. The Czech ISSP 2002 data contain detailed information about the histories of union formation, dissolution, and childbearing. They detail the month and year when a respondent started to live with their current stable partner and, where appropriate, the start and the end dates of their previous stable partnership. ${ }^{2}$ In addition, they provide the dates of birth of each child born to the respondent.

\section{The construction of early life trajectories}

On the basis of the above information I constructed partnership and parental trajectories. The analysis was restricted to events occurring between the ages of 18 and 35. This age interval represents the phase of the transition to adulthood, family formation, and early parenthood. In our data only $7.7 \%$ of women and $13.7 \%$ of men (born 1919-1967) remained childless at the age of 35. The trajectories of persons younger than 35 years were right-censored.

The trajectories were reconstructed from data in two steps. First, the age of the respondent was computed for each of the family changes (start/end of first/ second partnership, age at first childbirth). Then a set of 35 count variables representing six-month intervals from 18 to 35 years of age was created. The family trajectory reports six possible situations: if the respondent lived with a partner in unmarried cohabitation (U), was married $(\mathrm{M})$, or did not live with a partner $(\mathrm{S})$ and if they had a child (1) or not (0) at the beginning of each six-month interval (e.g. at the ages of $18,18.5 \ldots$ to 35 years). ${ }^{3}$ For instance, let us consider a woman who started to live with her first partner when she was 25 years old (U0); at the age of 29.5 years this partnership ended and she started living without a partner (S0). Later, when aged 31, she started to live with her second partner (U0) and a year later her first child was born (U1). In short, this family trajectory can be recorded as $(\mathrm{S} 0,14)-(\mathrm{U} 0,9)-(\mathrm{S} 0,3)-(\mathrm{U} 0,2)-(\mathrm{U} 1,7)$, where the second number within each set of parentheses indicates the number of six-month intervals.

For about $9.4 \%$ of respondents the trajectories cannot be reconstructed because no information about the date of entry into a partnership union is pro-

\footnotetext{
${ }^{2}$ Partnership was reported retrospectively and only three partners were traced (current, previous, and pre-previous partner). Consequently, we do not know if the pre-previous partner was the respondent's first partner, or if he or she lived in another partnership before that. For this reason only persons who lived with maximum two partners are included in the analyses reported (in total, 38 persons, $2.8 \%$ of the whole sample, were excluded) [cf. Hamplová 2003b].

${ }^{3}$ For more details on the construction of the trajectories, see Chaloupková [2009]. In terms of exactness, it would be ideal to observe the situation each month. However, in this case the trajectory length would increase enormously, which would make the subsequent analysis more difficult. Using six-month intervals, the time spent in a particular state could be under- or over-estimated at $+/-5$ months and short episodes occurring in the middle of the observed interval could remain under-reported.
} 
vided. Almost no data were missing on the date of childbirth. ${ }^{4} \mathrm{~A}$ respondent was included in the analysis even if some information was missing. This is because it makes sense to expect that more unstable trajectories, including many status changes, may have more missing data. Consequently, the following analysis uses all the trajectories, including those with gaps, ${ }^{5}$ to avoid potential under-representation of heterogeneity. In sum, 1433 trajectories were reconstructed: 734 for persons aged 35 years or older and 699 for persons younger than 35 years. From these, 19 trajectories of people over 35 years and 6 of those under age 35 contain some gaps. The episodes with missing information were coded as special 'missing episodes'.

\section{Measuring status heterogeneity}

To explore the diversity of status distribution by age in longitudinal life-course data I used the transversal entropy index [Fussell 2005; Widmer and Ritschard 2009]. The transversal entropy index measures the homogeneity of age-specific status combinations. ${ }^{6}$ Instead of analysing central tendencies relating to the age of family transitions or the family situation at a certain age, the entropy index of age-specific situations enables us to show the evolving trajectory in a holistic way. It shows the whole family formation process and indicates when the process of family related transitions begins and peaks and whether this pattern changes over time. The entropy index is zero if all individuals are in the same state, and a higher, non-zero entropy value indicates that the individuals examined are distributed over the different states (when the same proportion of individuals is in each state). To make the entropy index more comprehensible, I used the normalised entropy (which is divided by the maximum entropy value for a given state space). Normalised entropy has a maximum value of 1 and can be viewed as a percentage of the maximum entropy. ${ }^{7}$

In the second step I employed a decomposition of the entropy index as proposed by Fussell [2005]. To evaluate how each single status contributes to the total entropy index I calculated the percentage difference between total entropy

\footnotetext{
${ }^{4}$ The higher occurrence of missing data is connected with older age. There are no differences based on gender or education level.

${ }^{5}$ For example, when a respondent has lived with a second partner, but does not report the end of the first partnership (even if the start was known), the first partnership could not be coded and all periods prior to the start of the second partnership were coded as

missing data.
${ }^{6}$ Entropy is defined as follows: $E_{t}=-\sum_{j-1}^{q} p_{t j} \log \left(p_{t j}\right)$, where $p_{t j}$ is the proportion of individuals being in state $j$ (states $j=1, . . q$ ) at time $t$ [Rohwer and Potter 2005].

7 Given the fact that our state space includes six possible family status combinations (3 partnership statuses $\times 2$ parental statuses), the maximum entropy is $-(6 \times(1 / 6) \times$ $\log (1 / 6))=0.778$.
} 
and reduced entropy as measured when one of the statuses is excluded from the calculation [Fussell 2005]. I computed three reduced entropy indices: (1) without information about entry to parenthood; (2) without information on living with a partner; (3) without information about entry into marriage. ${ }^{8}$ This measure is calculated as the difference between the total entropy index and the reduced entropy index divided by the total entropy index. When the reduced entropy observed is higher than the heterogeneity predicted based on maximum entropy distributions ${ }^{9}$ it means that the contribution of the omitted status to age-specific status combination is relatively high [Fussell 2005].

\section{Identifying the patterns of early family trajectories}

To compare the similarities and dissimilarities in the sequences of states (trajectories), the Optimal Matching Analysis was used. Optimal matching techniques originated in the field of information theory and computer science, but subsequently spread to other scientific disciplines, particularly molecular biology and the study of DNA sequences [Lesnard 2006]. It was introduced into the social sciences by Andrew Abbott [Abbott 1995; Abbott and Hrycak 1990]. The optimal matching procedure rests on the idea that the more similar sequences are, the more easily they can be transformed from one to another. The distance between two sequences is measured by the total number of elementary operations (substitutions, insertions or deletions (indel)) necessary to transform one sequence into another. Each of these operations can be ascribed a specific weight, or what is known in the literature as 'cost'. Costs can weight the relative importance of indel operations to substitutions [Lesnard 2006], or in the case of substitution, higher costs can be assigned to substitutions of states that are more distant in reality. Cost can be assigned ad hoc, using theoretical criteria, but more often the cost is based on empirical data and is derived from the transition likelihoods between various states [Rohwer and Pötter 2005; Pollock 2007]. In this analysis I used the last-mentioned option. Pair distances computed by optimal matching were entered into clustering analysis in the form of a dissimilarity matrix. To identify distinct groups I used the Ward method of hierarchical clustering [Macindoe and

\footnotetext{
${ }^{8}$ In the first case we are only observing whether a respondent is living in unmarried cohabitation, in a marriage, or does not have a partner (3 states), in the second case we are interested only in whether the person is married or not and has a child or not (4 states), and finally we are observing whether he or she at a specific age lives with a partner and has a child or not (4 states).

9 The predicted percentage change when one status is omitted is calculated as the difference between the maximum total entropy and the maximum reduced entropy indices divided by the maximum total entropy. When information about having a child is omitted the maximum entropy reaches 0.477 and when information about unmarried cohabitation or marriage is omitted the maximum is 0.602 . That means that the predicted change is $(0.778-0.477) / 0.778=0.388$ (or 0.226 , respectively).
} 
Abbott 2004]. In the next step, logistic regression was used to identify the factors underlying these types. The sequence analysis was done using the TraMineR module (Trajectory mining in $\mathrm{R}$ ) in the statistical program $\mathrm{R}$ [Gabadinho et al. 2009].

\section{Exploring the heterogeneity of early family trajectories}

In the previous section it was argued that one can expect change in age-specific family status distribution in the youngest cohorts. To test whether the heterogeneity of trajectories increases over time, entropy measures for each cohort and gender group were computed. We can draw several conclusions from the evidence presented in Figure 1. The degree of family situation heterogeneity changes dramatically during the observed period of young adulthood. Entropy index ranges between $9 \%$ and $86 \%$ of maximum entropy. The variability of state distribution is the lowest at the age of 18 , when most young people have not yet experienced any of the transitions under observation: they are single, do not live with a partner, and have no children. Later, the heterogeneity of state distribution increases as young people start to pass these transitions and it reaches its peak around the age of 25. When they are in their thirties, the heterogeneity of their family situations declines as most of them have already experienced family related transitions.

Cohort comparison reveals three important trends. First, while in the older cohort the peak of heterogeneity was reached between the ages of 22 and 24, in the cohorts born in 1968-1979, who entered adulthood in the 1990s, the peak of heterogeneity shifted to the age of 26. Second, in the cohorts born in 1968-1979 it is possible to observe a higher level of heterogeneity in the distribution of family statuses, mainly in their late twenties and early thirties. Finally, in the youngest cohort (born in 1980-1984) the reverse trend is observed: a decline of diversity of family statuses at a younger age. These changes can be explained by the change in timing of family formation across cohorts to a higher age. The changes in the youngest cohort can be interpreted in line with the hypothesis of early family lifecourse (partial) standardisation, because the distribution of family situations in the youngest cohort's twenties becomes more homogenous than in the previous birth cohorts.

To analyse cohort and age differences in more detail, a regression analysis was run on age-specific entropy measures computed separately for each gender and cohort group (Table 1). OLS regression enabled testing for any significant cohort, age, and gender differences. Analysis confirmed that the demographic behaviour of the cohort born in 1962-1967, who entered adulthood just around 1989 (or several years before) is more similar to that of older cohorts who lived under the communist regime. This conforms to findings in previous literature showing that the demographic changes in post-communist countries affected the birth cohort born in the 1970s and later [Sobotka et al. 2008]. Compared to older cohorts a 
Figure 1. Heterogeneity of family status distribution between 18 and 35 years across cohorts

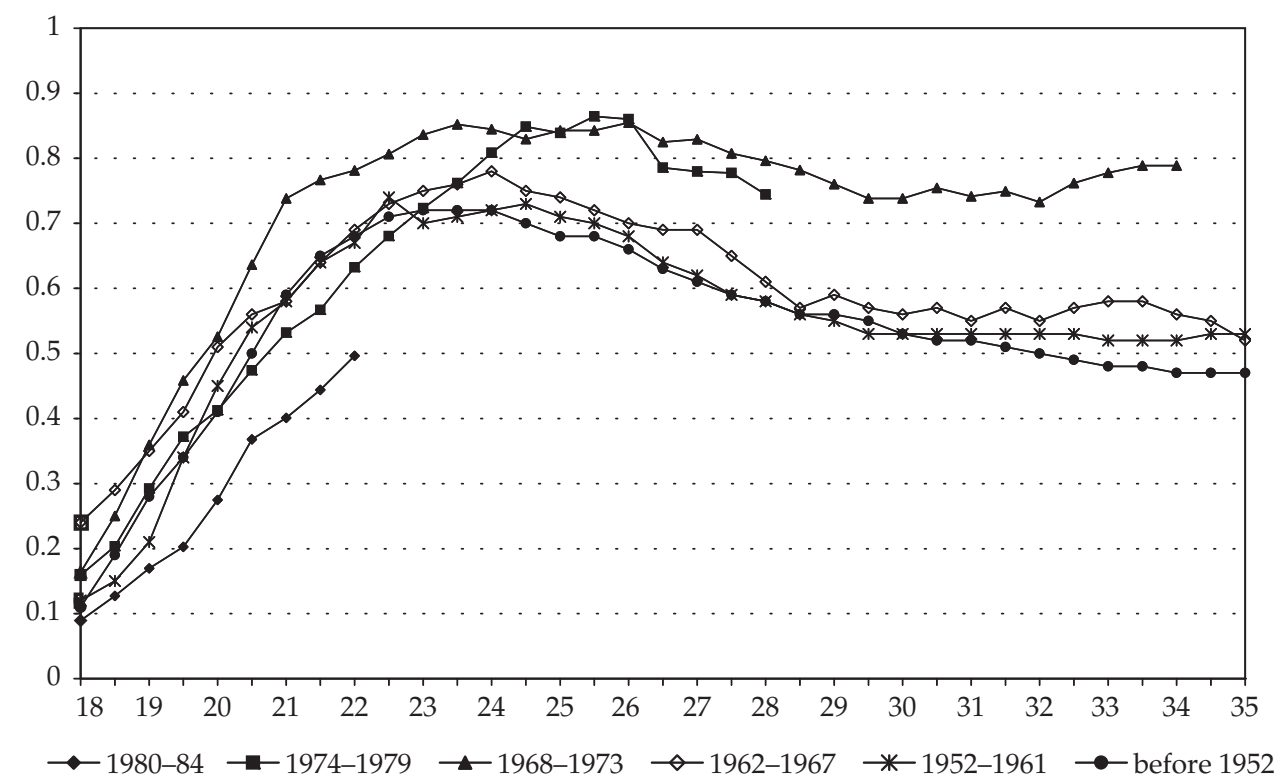

Source: ISSP 2002 (with oversample).

Notes: Normalised index of transversal entropy.

significant increase of heterogeneity is observed in the cohorts born in 1974-1979 and 1968-1973, who entered adulthood after 1989. By contrast, there was a certain simplification of family trajectories (lower heterogeneity of status combinations) in the youngest cohort born between 1980 and 1984. It is important to note that persons in this birth cohort had not yet completed the whole life phase under observation (18-35 years). These changes reflect only the beginning of their family trajectories - the period between the ages of 18 and 22. The heterogeneity can be expected to increase more steeply at a higher age.

The analysis confirms that family status distribution is less diverse up to the age of 20 and then increases during the mid-twenties and slightly decreases after the age of 30. The variability of family status distribution differs according to gender. Women's early family trajectories are more diverse than men's at all ages. The gender gap varies by age and is largest when young people are in their early twenties, which reflects the fact that men experience family-related transitions at a higher age than women. Moreover, gender differences are stronger in the youngest generation (1974-1984 birth cohorts) than in the older cohorts, which means that the family situations of women are even more complex than men's. 


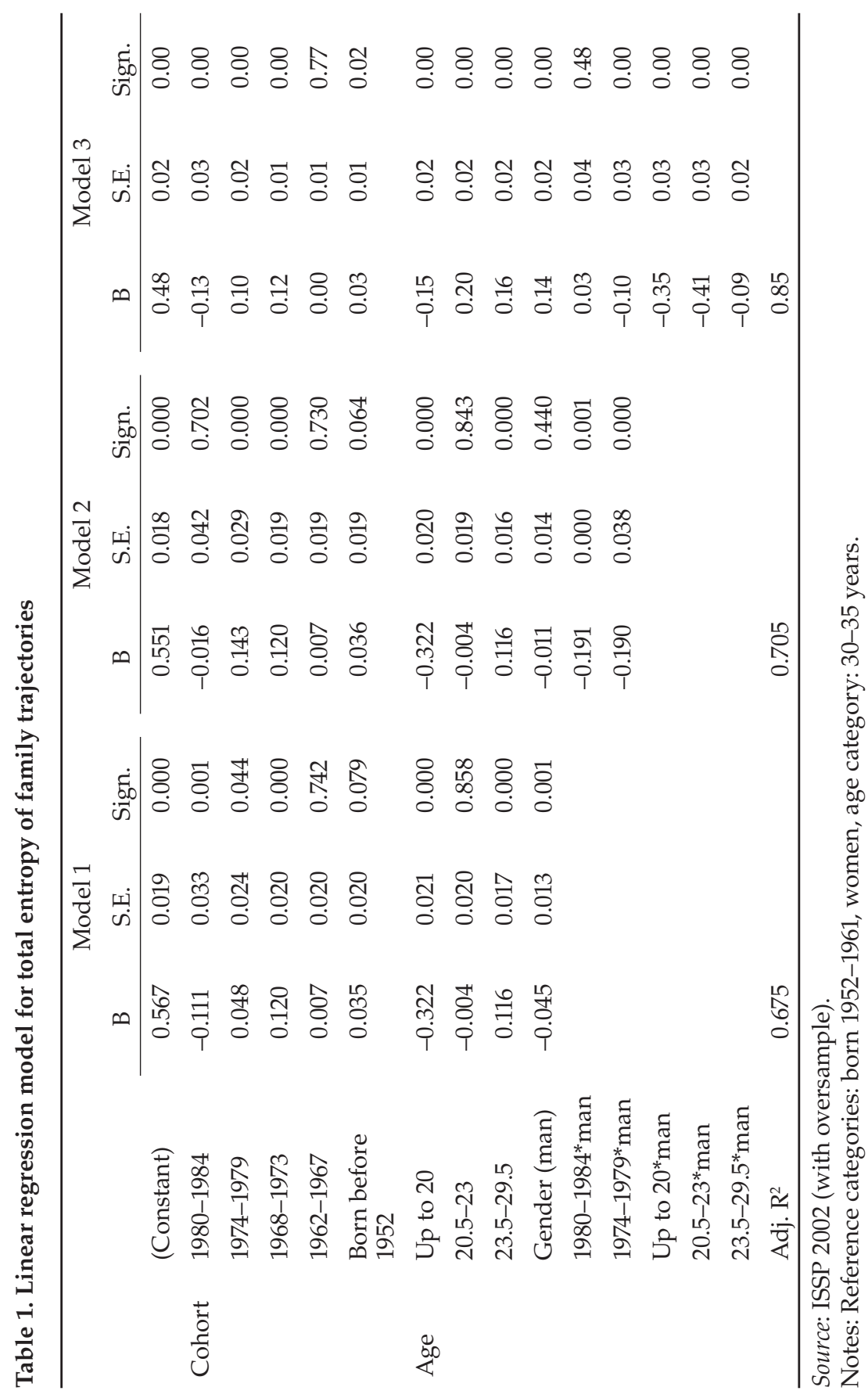


Table 2. Average percentage decrease in entropy index due to omitting one status

\begin{tabular}{|c|c|c|c|c|c|c|c|}
\hline \multirow[t]{2}{*}{ Birth cohort } & \multirow[t]{2}{*}{ Age } & \multicolumn{2}{|c|}{$\begin{array}{l}\text { Without entry to } \\
\text { parenthood* }\end{array}$} & \multicolumn{2}{|c|}{$\begin{array}{l}\text { Without partner- } \\
\text { ship status** }\end{array}$} & \multicolumn{2}{|c|}{$\begin{array}{l}\text { Without entry to } \\
\text { marriage }^{* *}\end{array}$} \\
\hline & & Women & Men & Women & Men & Women & Men \\
\hline \multirow[t]{2}{*}{ 1980-1984 } & up to 20 & 1.5 & 8.0 & 47.9 & 8.1 & 4.2 & 0.0 \\
\hline & $20.5-23$ & 16.2 & 9.3 & 62.7 & 57.3 & 19.5 & 4.0 \\
\hline \multirow[t]{3}{*}{ 1974-1979 } & up to 20 & 10.8 & 9.9 & 56.7 & 26.0 & 12.7 & 7.5 \\
\hline & $20.5-23$ & 36.0 & 11.9 & 74.9 & 44.1 & 36.9 & 21.7 \\
\hline & $23.5-29.5$ & 51.1 & 28.6 & 65.0 & 46.9 & 60.3 & 32.0 \\
\hline \multirow[t]{4}{*}{ 1968-1973 } & up to 20 & 16.5 & 10.6 & 46.4 & 20.9 & 23.0 & 3.5 \\
\hline & $20.5-23$ & 46.3 & 16.7 & 52.9 & 31.3 & 46.1 & 5.7 \\
\hline & $23.5-29.5$ & 50.2 & 46.6 & 47.8 & 61.0 & 59.9 & 55.7 \\
\hline & $30-35$ & 23.6 & 40.0 & 40.0 & 61.8 & 64.1 & 60.6 \\
\hline \multirow[t]{4}{*}{ 1962-1967 } & up to 20 & 32.7 & 9.9 & 14.2 & 19.3 & 8.0 & 2.2 \\
\hline & $20.5-23$ & 47.9 & 24.4 & 24.0 & 36.4 & 17.1 & 17.8 \\
\hline & $23.5-29.5$ & 45.4 & 46.7 & 23.5 & 32.3 & 28.7 & 28.8 \\
\hline & $30-35$ & 24.6 & 49.2 & 22.1 & 21.0 & 46.8 & 30.8 \\
\hline \multirow[t]{4}{*}{ 1952-1964 } & up to 20 & 16.1 & 6.9 & 24.5 & 6.8 & 13.8 & 3.0 \\
\hline & $20.5-23$ & 43.0 & 24.1 & 40.3 & 25.7 & 37.9 & 17.5 \\
\hline & $23.5-29.5$ & 44.1 & 51.8 & 19.6 & 31.1 & 44.5 & 31.3 \\
\hline & $30-35$ & 24.1 & 48.2 & 22.8 & 20.8 & 46.9 & 30.7 \\
\hline \multirow[t]{4}{*}{ Before 1952} & up to 20 & 17.6 & 5.4 & 26.4 & 9.3 & 11.6 & 1.7 \\
\hline & $20.5-23$ & 53.1 & 26.2 & 31.5 & 28.2 & 33.8 & 18.5 \\
\hline & $23.5-29.5$ & 56.1 & 58.0 & 20.4 & 27.2 & 36.3 & 40.8 \\
\hline & $30-35$ & 37.7 & 46.9 & 19.9 & 20.5 & 38.5 & 38.9 \\
\hline
\end{tabular}

Source: ISSP 2002 (with oversample).

Notes: * the expected percentage change is $38.7 ; * *$ the expected percentage change is 22.6. When the observed change is higher than the expected value, the value is marked in bold.

Which statuses contribute most to the overall diversity in early trajectories? What are the sources of the overall diversity in early trajectories? More specifically, what statuses contribute to an increase of diversity over time? In order to find how much each status contributes to total entropy, I computed the percentage change in the entropy index excluding the information about entry into parenthood, living with a partner, and marriage for each age, cohort, and gender group (Table 2). The values in bold indicate a higher than expected percent- 


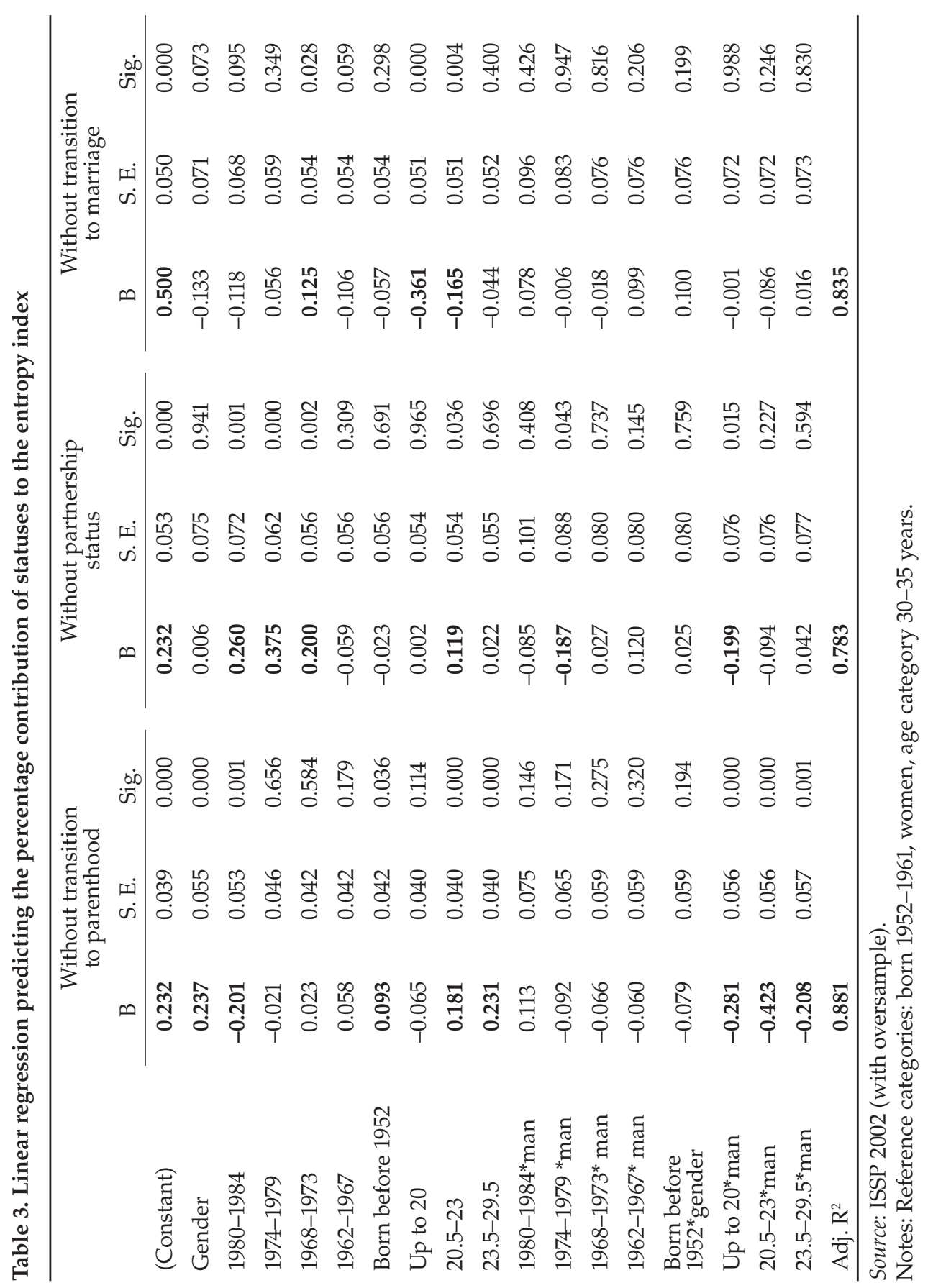


age change when the particular status is omitted. The findings confirm that the contribution of certain states to overall heterogeneity varies by age, cohort, and gender.

The decomposition analysis helps us explain the change of early family trajectories. A large change resulting from the omission of a status shows that this status creates many status combinations, or that either very large or very small proportions of population hold that status. At the age when all persons are single and childless, omitting the parental status would not change the entropy index at all since being single is completely associated with childless status. However, if there are also people who are single but have a child, we would observe a change between the total and reduced entropy indices.

The results of the regression analysis confirm that it is mainly partnership status that contributes to the heterogeneity of the family situations of the cohorts entering adulthood in the 1990s, while both parenthood and marriage are less important (Table 3). However, the importance of partnership status differs by age and gender, being greater in the twenties and for women. Conversely, the marriage status contribution is lower in the twenties. Women experience higher levels of heterogeneity due to partnership and parenthood statuses in their twenties compared to men. Differentiation by these statuses between genders increases in the youngest cohorts. The transition to parenthood contributes to the increased heterogeneity of the family situations of people in their twenties, with the exception of the youngest cohorts born from the mid-1970s on. Unlike men, for women after the age of 30 the contribution of parenthood transition to overall heterogeneity declines, as by then an increasing proportion of young women already have a child.

\section{Types of early family trajectories}

The above analysis dealt only with the completed trajectories of people aged 35 or older (471 women and 263 men). Because persons younger than 35 years were excluded, the youngest cohort observed here was born between 1962 and 1967. Although they were 22-27 years old in 1989 when the communist regime collapsed, they spent the majority of their lives up to the age of 35 in the new social, economic, and political conditions after 1989, unlike the older cohorts.

Using pair distances computed by the optimal matching procedure, the cluster analysis revealed five clearly distinct and meaningful family trajectories types. ${ }^{10}$ The five cluster solution was chosen based on a comparison of the relative improvement in the ratio of within- and between-cluster distances between solu-

\footnotetext{
${ }^{10}$ For the optimal matching procedure, the substitution costs were derived from the frequency of transitions between six observed states in the given data. It is based on the simple idea that two states are less different when there are fewer transitions from one state
} 
Table 4. Average time spent in each family situation between the ages of $\mathbf{1 8}$ and 35

\begin{tabular}{|c|c|c|c|c|c|}
\hline & 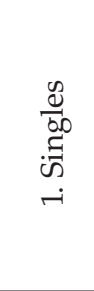 & 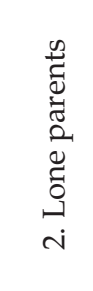 & 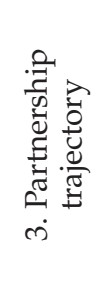 & 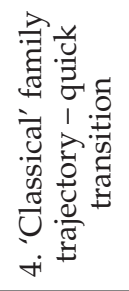 & 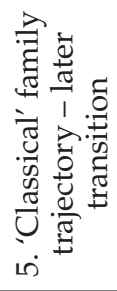 \\
\hline Marriage, no child (M0) & 2.04 & 0.91 & 12.60 & 1.94 & 3.58 \\
\hline Marriage, child (M1) & 0.59 & 3.04 & 1.39 & 26.51 & 16.32 \\
\hline $\begin{array}{l}\text { Unmarried cohabitation, } \\
\text { no child (U0) }\end{array}$ & 0.84 & 0.30 & 1.50 & 0.31 & 0.65 \\
\hline $\begin{array}{l}\text { Unmarried cohabitation, } \\
\text { child (U1) }\end{array}$ & 0.00 & 0.04 & 4.31 & 0.14 & 0.16 \\
\hline $\begin{array}{l}\text { Not living with partner, } \\
\text { no child (S0) }\end{array}$ & 31.45 & 9.39 & 7.46 & 5.73 & 13.61 \\
\hline $\begin{array}{l}\text { Not living with partner, } \\
\text { child (S1) }\end{array}$ & 0.08 & 21.23 & 0.42 & 0.31 & 0.68 \\
\hline $\mathrm{N}$ & 74 & 57 & 72 & 339 & 192 \\
\hline
\end{tabular}

Source: ISSP 2002, 35+.

Notes: Values show the average number of six-month intervals (max. 35). Due to the method of construction their purpose is mainly to illustrate the type's differences.

tions with different numbers of clusters (see the table in Appendix 2). The basic rule for the choice of cluster solution is that the mean within-cluster distance is not higher than half of the mean between-cluster distance [Aisenbrey and Fasang 2007]. The key advantage of following this rule is that it provides a convenient means of selecting the minimum number of clusters that provide a good fit to the data.

into the other. The transition rates between states $i$ and $j$ are the probability of observing state $j$ at time $t+1$ given that state $i$ has been observed at time $t$ [Gabadinho et. al. 2009]. The estimated transition rates range from 1.93 to 2 (see Appendix). The indel cost was set at value of 1 (i.e. half of the highest substitution cost). However, it is important to note that these substitution costs are time-independent, thus the analysis does not take into account that the transition between two specific states can became easier or more difficult over time (or between birth cohorts). Nevertheless, the previous analysis done by the author using time-varying substitution costs (dynamic Hamming dissimilarity measure), which calculates separate substitution cost matrices for each age based on the frequency of transition between states at this given age [Lesnard 2006], did not show substantively different results. 
The dominant types of early family trajectories include family formation and entry to parenthood (types 4 and 5) (Table 4). The most common family trajectory, experienced by roughly three-quarters of women and more than $60 \%$ of men, was the classical family trajectory starting with entry into a partnership union (typically marriage) and subsequent parenthood. However, there was variability in the timing of these transitions. More than half of women and about $30 \%$ of men followed the classical family trajectory with quick entry to marriage and parenthood, while the others postponed these transitions to a higher age. Whereas in the first group the median age of childbirth was 21.4 years for women, in the second group it was almost five years higher (26.6 years). Even in the older cohorts, who experienced the period under investigation during the socialist period, it was possible to identify less standard trajectories, such as trajectories centred on partnership, singles' trajectories, and lone-parent trajectories. Around $18 \%$ of men and $6 \%$ of women followed the trajectory of singles, not living with a partner and remaining childless for most of the period under observation. The partnership trajectory was another specific trajectory, consisting of entry to unmarried cohabitation or marriage without immediately making the transition to parenthood. This type of trajectory was experienced by $9 \%$ of women and $11 \%$ of men. Unlike other family trajectory types, only a minority of persons who followed the singles' and partnership trajectory became parents before the age of $35 .^{11}$ The last type of early family trajectory was that of lone parents (typically divorced), experienced by $9 \%$ women and $6 \%$ of men. Note that the survey did not ask whether parents co-resided with their children, so this group also includes persons who do not share a household with their children. This trajectory typically includes a quick transition to marriage, childbirth, and divorce or childbearing outside of marriage.

A simple cross-tabulation of cluster membership reveals that almost $25 \%$ of university educated people followed the singles' trajectory, while the proportion of people with secondary education who followed the singles' trajectory was only $6 \%$. People with higher education were also more likely to experience later transitions to parenthood (Table 5).

A comparison of the distribution of trajectory types across cohorts revealed no significant differences and it seems that the family behaviour of the 1962-1967 birth cohort, who entered adulthood around the time of the fall of the communist regime, is in many respects similar to the older cohorts who became adults under the communist regime. This is due to the fact that a relatively large share of them had already started a family by the time the communism regime collapsed. A closer look shows that in 1989 almost 55\% of the youngest cohort had experienced the transition to parenthood. If we look only at the members of this

${ }^{11}$ While in the other groups all persons experienced the transition to parenthood before the age of 35 (and in group 4 even before the age of 25), only $21 \%$ of singles and $54 \%$ of those who followed the parental trajectory had a child before the age of 35 . Note that these figures do not reflect 'completed' fertility/childlessness. 
Table 5. Socio-demographic characteristics of family trajectory types (row \%)

\begin{tabular}{|c|c|c|c|c|c|c|c|}
\hline & & 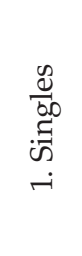 & 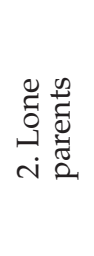 & 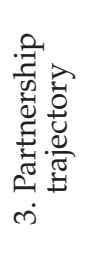 & 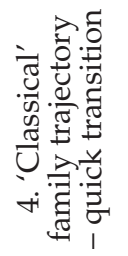 & 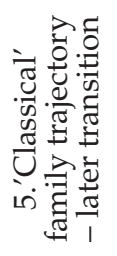 & 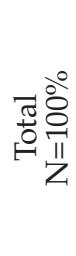 \\
\hline \multirow[t]{2}{*}{ Gender*** } & Women & 5.9 & 8.7 & 8.9 & 55.2 & 21.2 & 531 \\
\hline & Men & 17.5 & 6.1 & 11.4 & 30.0 & 35.0 & 263 \\
\hline \multirow[t]{3}{*}{ Education $^{* * *}$} & $\begin{array}{l}\text { Without } \\
\text { high school } \\
\text { diploma }\end{array}$ & 9.9 & 7.9 & 11 & 46.7 & 24.5 & 445 \\
\hline & $\begin{array}{l}\text { Full } \\
\text { secondary }\end{array}$ & 6.4 & 8.2 & 8.2 & 54.7 & 24.5 & 220 \\
\hline & University & 23.4 & 3.1 & 7.8 & 21.9 & 43.8 & 64 \\
\hline \multirow[t]{5}{*}{ Cohort } & Before 1952 & 8.6 & 8.3 & 10.8 & 46.7 & 25.7 & 362 \\
\hline & 1952-1961 & 10.7 & 5.2 & 10.7 & 46.8 & 26.6 & 233 \\
\hline & 1962-1967 & 12.9 & 10.8 & 5.8 & 43.9 & 26.6 & 139 \\
\hline & (1) & 29.0 & 3.2 & 11.3 & 9.7 & 46.8 & 62 \\
\hline & (2) & 0.0 & 16.9 & 1.3 & 71.4 & 10.4 & 77 \\
\hline
\end{tabular}

Source: ISSP 2002, 35+.

Notes: Chi $^{2}$ Test, ${ }^{* * *} \mathrm{p}<0.001$. (1) have not experienced the transition to parenthood before $1989,(2)$ have experienced the transition to parenthood before 1989.

birth cohort who did not yet have a child in 1989, we get a much different picture (Table 5). The members of the youngest generation who had no family commitments in 1989 followed more often the singles trajectory and the classical family trajectory with later transitions.

In order to understand the relationship between education, gender, cohort, and the probability of experiencing a specific type of family trajectory, I used cluster membership as a dependent variable in a multinomial logistic regression (Table 6). The findings confirm that being university educated and being male increases the likelihood of a person experiencing the singles' trajectory and the classical family trajectory with a later transition to marriage and parenthood. The partnership trajectory, which entails living with a partner and delaying childbearing, was also more typical for men. The fact that highly educated people have a greater likelihood of experiencing family trajectories with delayed entry into a partnership union and childbearing might be explained by the longer period of educational enrolment. 


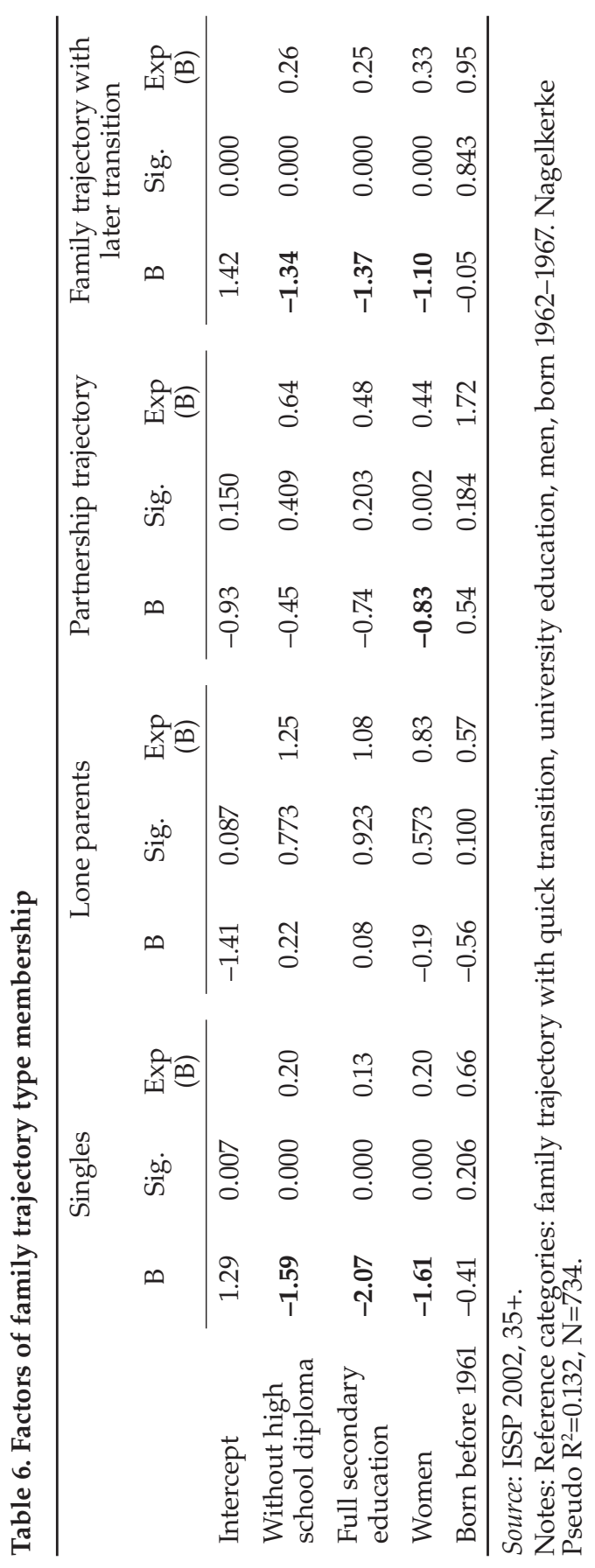


In this analysis, the distribution of trajectory types among persons born up to 1961 was compared with the birth cohort of 1962-1967, which entered adulthood around the fall of the communist regime. However, the analysis did not reveal significant differences in the distribution of family trajectory types in the cohort of 1962-1967. These results are in line with the findings of entropy analysis, which suggested that demographic behaviour in this cohort was in many respects quite similar to the older cohorts who lived under the communist regime.

\section{Conclusion and discussion}

Using the trajectory-based approach, this paper focused on the period of family formation in the lives of people in the Czech Republic. Data from the ISSP 2002 on 'Family and Changing Gender Roles', which contain information on union formation and childbearing history, were used to reconstruct individual family trajectories of people between the ages of 18 and 35. Complete trajectories could only be reconstructed for people who were at least 35 years old in 2002. However, for the analysis of age-specific family status distribution, data on younger people were also used in order to capture more recent changes in demographic behaviour.

The trajectory-based perspective revealed five distinct sequence patterns of early family trajectories. The analyses showed that even among older age cohorts which experienced their family starts under the socialist regime it was possible to find some plurality of family starts, differentiated by level of education. Nevertheless, this plurality was limited.

The entropy analysis enabled us to examine change in the diversity of family status combinations across birth cohorts. It partially confirmed the de-standardisation hypothesis. Cohorts born from the 1970s on, who started a family under the new social conditions after 1989, experienced more diverse early family trajectories than older cohorts. At the same time, the peak of heterogeneity shifted to an age after 25, reflecting the trend of postponing family formation. The analysis also showed that the heterogeneity of family situations increased more for women than for men. The increase of heterogeneity was mainly the result of the spread of unmarried cohabitation and the rising number of people living without a partner.

However, the analysis confirmed that the process of de-standardisation was quite complex and non-uniform. In the cohort born in the 1980s we could observe a reversal trend of declining family status diversity at the beginning of the observed period of transition to adulthood. As a result of the postponement of family related transitions, we observed a certain simplification of family situations in the early twenties in the youngest cohort. It is important to note that persons in this birth cohort had not completed the entire life period under observation and these changes reflected only the beginning of their family trajectories. We may expect that the heterogeneity will increase at higher ages. 
Entropy indices were computed for each gender and cohort group. However, we may expect that there are other factors which structure a life course, such as socio-economic status. Due to its size, the sample could not be broken down into a higher number of groups (e.g. groups according to educational level, gender, and cohort). Trajectory-based analysis is very demanding in terms of the quality of data collection. Given the fact that people with highly complex trajectories are more likely to have more missing information, heterogeneous trajectories may be underrepresented [Aassve, Billari and Piccarreta 2007]. This implies that the trajectories examined might be in reality even more heterogeneous than indicated here. Notwithstanding this limitation, the findings of this analysis can contribute to a better understanding of complex changes in early family trajectories in the Czech Republic.

Jana Chaloupková is a junior researcher at the Institute of Sociology, Academy of Sciences of the Czech Republic, and currently she is finishing her PhD dissertation at the Faculty of Arts, Charles University in Prague. Her main research interests include family studies, particularly changes to work and family from the life-course perspective and attitudes towards family.

\section{References}

Aassve, Arnstein, Francesco Billari and Raffaella Piccarreta. 2007. 'Strings of Adulthood: a Sequence Analysis of Young British Women's Work-family Trajectories.' European Journal of Population 23 (3-4): 369-388.

Abbott, Andrew. 1995. 'Sequence Analysis: New Methods for Old Ideas.' Annual Review of Sociology 21: 93-113.

Abbott, Andrew and Alexandra Hrycak. 1990. 'Measuring Resemblance in Sequence Data: an Optimal Matching Analysis of Musicians' Careers.' American Journal of Sociology 96 (1): 144-185.

Aisenbrey, Silke and Anette E. Fasang. 2007. 'Beyond Optimal Matching: the "Second Wave" of Sequence Analysis.' Working Paper 2007-02. New Haven: Yale University, The Center for Research on Inequalities and the Life Course.

Alan, Josef. 1989. Etapy života očima sociologie (Life Stages from a Sociological Perspective). Prague: Panorama.

Baranowska, Anna. 2008. 'Changing Patterns of Entry into Employment and Motherhood in Poland - a Cross Cohort Comparison.' Social Sciences Research Network TransEurope Working Paper No. 5. Bamberg: Otto-Friedrich-University Bamberg.

Beck, Ulrich. 2004. Riziková společnost. Na cestě k jiné modernitě (Risk Society: Towards a New Modernity). Prague: Sociologické nakladatelství.

Becker, Gary, S. 1993. A Treatise on the Family. Cambridge: Harvard University Press.

Billari, Francesco C. 2001. 'Sequence Analysis in Demographic Research.' Canadian Studies in Population 28 (2): 439-458.

Billari, Francesco C. 2005. 'Life Course Analysis: Two (Complementary) Cultures? Some Reflections with Examples from the Analysis of the Transition to Adulthood.' Pp. 261-282 in Towards an Interdisciplinary Perspective on the Life Course. Advances in Life 
Course Research, edited by René Levy, Paolo Ghisletta, Jean-Marie Le Goff, Dario Spini and Eric Widmer. London: Elsevier.

Billari, Francesco C. and Dimiter Philipov 2004. 'Women's Education and Entry into a First Union. A Simultaneous-hazard Comparative Analysis of Central and Eastern Europe.' Vienna Yearbook of Population Research: 91-110.

Blossfeld, Hans-Peter and Johannes Huinink. 1991. 'Human Capital Investments or Norms of Role Transition? How Women's Schooling and Career Affect the Process of Family Formation.' American Journal of Sociology 97 (1): 143-168.

Brückner, Hannah and Karl Ulrich Mayer. 2005. 'De-standardization of the Life Course: What Might It Mean? And If It Means Anything, Whether It Actually Took Place?' Pp. 27-53 in The Structure of the Life-course: Standardized? Individualized? Differentiated?, edited by Ross Macmillan. London: Elsevier.

Brzinsky-Fay, Christian, Ulrich Kohler and Magdalena Luniak. 2006. 'Sequence Analysis with Stata.' Stata Journal 6 (4): 435-460.

Chaloupková, Jana. 2009. 'Rodinné a pracovní dráhy mladých: holistická perspektiva' (Family and Work Trajectories of Young People: a Holistic Perspective). Sociologické studie/Sociological Studies 09:07. Prague: Sociologický ústav AV CR.

Elzinga, Cees H. and Aart C. Liefbroer. 2007. ‘De-standardization of Family-Life Trajectories of Young Adults: a Cross-National Comparison Using Sequence Analysis.' European Journal of Population 23 (3-4): 225-250.

Fussell, Elizabeth. 2005. 'Measuring the Early Adult Life Course: an Application of the Entropy Index.' Pp. 91-122 in The Structure of the Life Course: Standardized? Individualized? Differentiated?, edited by Ross Macmillan. London: Elsevier.

Fussell, Elizabeth, Anne Gauthier and Ann Evans. 2007. 'Heterogeneity in the Transition to Adulthood: the Cases of Australia, Canada, and the United States.' European Journal of Population 23 (3-4): 389-414.

Gabadinho, Alexis, Gilbert Ritschard, Matthias Studer and Nicalas S. Müller. 2009. Mining Sequence Data in $R$ with the TraMineR Package: A User's Guide for Version 1.2. Geneva: University of Geneva.

Giele, Janet Z. and Glen H. Elder. 1998. 'Life Course Research: Development of a Field.' Pp. 5-27 in Methods of Life Course Research. Qualitative and Quantitative Approaches, edited by Janet Z. Giele and Glen H. Elder. London: Sage.

Hamplová, D. 2003a. 'Vstup do manželství a nesezdaného soužití v České republice po roce 1989 v souvislosti se vzděláním' (Entry into Marriage and Unmarried Cohabitation in the Czech Republic after 1989 in Connection with Education). Sociologické texty/Sociological Papers SP 03: 04. Prague: Sociologický ústav AV ČR.

Hamplová, D. 2003b. 'Marriage and Educational Attainment: A Dynamic Approach to First Union Formation.' Sociologický časopis/Czech Sociological Review 39 (6): 841-863.

Hamplová, D. (ed.) 2007. Děti na psí knížku? Mimomanželská plodnost v ČR (Children without Marriage or without Fathers? Non-marital Fertility in the Czech Republic). Prague: Sociologický ústav AV ČR.

Kantorová, Vladimíra. 2004. 'Education and Entry into Motherhood: the Czech Republic during State Socialism and the Transition Period (1970-1997).' Demographic Research. Retrieved 16 March 2010 (http://www.demographic-research.org/special/3/10/).

Kohli, Martin. 1986. 'The World We Forgot: a Historical Review of the Life Course.' Pp. 271-303 in Later Life. The Social Psychology of Aging, edited by W. V Marshal. London: Sage.

Kocourková, Jiřina. 2002. 'Leave Arrangements and Childcare Services in Central Europe: Policies and Practices before and after Transition.' Community, Work and Family 5 (3): 301-318.

Kreyenfeld, M. 2000. ‘Educational Attainment and First Birth: East Germany before and 
after Unification.' MPIDR Working Paper WP 2000-11. Rostock: Max Plank Institute for Demographic Research.

Kreyenfeld, M. 2004. 'Fertility Decisions in the FRG and GDR: an Analysis with Data from the German Fertility and Family Survey.' Demographic Research. Special Collection 3, Article 11. Retreived 16 March 2010 (www.demographic-research.org).

Lesnard, Laurent. 2006. Optimal Matching and the Social Sciences. Document de travail du Crest. Paris: INSEE.

Levy, René, Jacques-Antoine Gauthier and Eric Widmer. 2006. ‘Entre contraintes institutionnelle et domestique: les parcours de vie masculins et féminins en Suisse.' Canadian Journal of Sociology 31 (4): 461-489.

Levy, René and Helga Krüger. 2001. 'Linking Life Courses, Work and the Family: Theorizing a Not So Visible Nexus between Women and Men.' Canadian Journal of Sociology 26 (2): 145-166.

Macindoe, Heather and Andrew Abbott. 2004. 'Sequence Analysis and Optimal Matching Technique for Social Science Data.' Pp. 387-406 in Handbook of Data Analysis, edited by Melissa Hardy and Alan Bryman. London: Sage Publications.

Mills, Melinda and Hans-Peter Blossfeld. 2005. 'Globalization, Uncertainty and the Early Life Course: a Theoretical Framework.' Pp. 1-24 in Globalization, Uncertainty and Youth in Society, edited by Melinda Mills, Hans-Peter Blossfeld, Eric Klijzing and Karin Kurz. London: Routledge.

Paloncyová, Jana. 2002. Rodinné chování mladé generace. Závěrečná zpráva z Biografického výzkumu mladé generace 2002 (Family Behaviour of the Young Generation: Final Report from the Young Generation Biographical Survey 2002). Prague: Výzkumný ústav práce a sociálních věcí.

Pollock, Gary. 2007. 'Holistic Trajectories: a Study of Combined Employment, Housing and Family Careers by Using Multiple-sequence Analysis.' Journal of the Royal Statistical Society: Series A (Statistics in Society) 170 (1): 167-183.

Rohwer, Götz and Ulrich Pötter. 2005. TDA User's Manual. Bochum: Ruhr-Universität Bochum.

Sobotka, Tomáš, Anna Štastná, Kryštof Zeman, Dana Hamplová and Vladimíra Kantorová. 2008. 'Czech Republic: a Rapid Transformation of Fertility and Family Behaviour after the Collapse of State Socialism.' Demographic Research 19: 403-454.

Večerník, Jiří. 1999. 'Inequalities in Earnings, Income and Household Wealth.' Pp. 115-136 in Ten Years of Rebuilding Capitalism. Czech Society after 1989, edited by Jiří Věčerník and Petr Matějů. Prague: Academia.

Widmer, Eric D. and Gilbert Ritschard. 2009. 'The De-standardization of the Life Course: Are Men and Women Equal?' Advances in Life Course Research 14 (1-2): 28-39. 


\section{Appendices}

Appendix 1. Substitution costs matrix for optimal matching analysis

\begin{tabular}{llllllll}
\hline & M1 & M0 & S0 & S1 & U1 & U0 & $*$ \\
\hline M1 & 0.00 & & & & & & \\
M0 & 1.80 & 0.00 & & & & & \\
S0 & 2.00 & 1.94 & 0.00 & & & & \\
S1 & 1.97 & 2.00 & 1.99 & 0.00 & & & \\
U1 & 1.93 & 2.00 & 2.00 & 1.98 & 0.00 & & \\
U0 & 1.98 & 1.80 & 1.98 & 2.00 & 1.96 & 0.00 & \\
$*$ & 2.00 & 2.00 & 2.00 & 2.00 & 2.00 & 2.00 & 2.00 \\
\hline
\end{tabular}

Source: ISSP 2002, 35+.

Notes: indel costs $=1$.

Appendix 2. Within- and between-cluster distances

\begin{tabular}{lccccl}
\hline $\begin{array}{c}\text { No. } \\
\text { of clusters }\end{array}$ & $\begin{array}{c}\text { Average } \\
\text { within- } \\
\text { cluster } \\
\text { distances } \\
(\mathrm{w})\end{array}$ & $\begin{array}{c}\text { Average } \\
\text { between- } \\
\text { cluster } \\
\text { distances } \\
(\mathrm{b})\end{array}$ & $\mathrm{W} / \mathrm{b}$ ratio & $\begin{array}{c}\text { Difference } \\
\text { of w } / \mathrm{b} \\
\text { ratio }\end{array}$ & Cluster size \\
\hline 2 & 20.358 & 50.940 & 0.400 & & 203531 \\
3 & 18.551 & 51.127 & 0.363 & 0.037 & 14657531 \\
4 & 17.351 & 51.155 & 0.339 & 0.024 & 745772531 \\
5 & $\mathbf{1 2 . 7 9 5}$ & $\mathbf{4 1 . 3 7 5}$ & $\mathbf{0 . 3 0 9}$ & $\mathbf{0 . 0 3 0}$ & 745772339192 \\
6 & 12.042 & 41.504 & 0.290 & 0.019 & 74573933919233 \\
7 & 11.882 & 41.530 & 0.286 & 0.004 & 7457393391921617 \\
\hline
\end{tabular}

Source: ISSP 2002, 35+. 